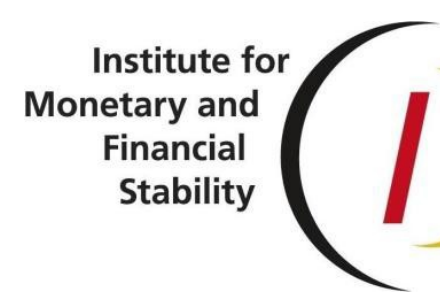

ATHANASIOS ORPHANIDES

\title{
Are Rules and Boundaries Sufficient to Limit Harmful Central Bank Discretion? Lessons from Europe
}


This Working Paper is issued under the auspices of the Institute for Monetary and Financial Stability (IMFS). Any opinions expressed here are those of the author(s) and not those of the IMFS. Research disseminated by the IMFS may include views on policy, but the IMFS itself takes no institutional policy positions.

The Institute for Monetary and Financial Stability aims at raising public awareness of the importance of monetary and financial stability. Its main objective is the implementation of the "Project Monetary and Financial Stability" that is supported by the Foundation of Monetary and Financial Stability. The foundation was established on January 1, 2002 by federal law. Its endowment funds come from the sale of $1 \mathrm{DM}$ gold coins in 2001 that were issued at the occasion of the euro cash introduction in memory of the D-Mark.

The IMFS Working Papers often represent preliminary or incomplete work, circulated to encourage discussion and comment. Citation and use of such a paper should take account of its provisional character.

\section{Institute for Monetary and Financial Stability}

Goethe University Frankfurt

House of Finance

Grüneburgplatz 1

D-60323 Frankfurt am Main

www.imfs-frankfurt.de | info@imfs-frankfurt.de 


\title{
Are Rules and Boundaries Sufficient to Limit Harmful Central Bank Discretion? Lessons from Europe
}

\author{
Athanasios Orphanides*
}

MIT

October 2014

\begin{abstract}
Marvin Goodfriend's (2014) insightful, informative and provocative work explains concisely and convincingly why the Fed needs rules and boundaries. This paper reviews the broader institutional design problem regarding the effectiveness of the central bank in practice and confirms the need for rules and boundaries. The framework proposed for improving the Fed incorporates key elements that have already been adopted in the European Union. The case of ELA provision by the ECB and the Central Bank of Cyprus to Marfin-Laiki Bank during the crisis, however, suggests that the existence of rules and boundaries may not be enough to limit harmful discretion. During a crisis, novel interpretations of the legal authority of the central bank may be introduced to create a grey area that might be exploited to justify harmful discretionary decisions even in the presence of rules and boundaries. This raises the question how to ensure that rules and boundaries are respected in practice.

Keywords: Rules, discretion, central bank mandates, ECB, Central Bank of Cyprus, ELA.

JEL Classification: E58, E61.
\end{abstract}

*Written for the Hoover Institution Conference, Frameworks for Central Banking in the Next Century, Stanford University, Palo Alto, CA, May 29-30, 2014. Correspondence: MIT Sloan School of Management, E62-481, 100 Main Street, Cambridge, MA 02142. Tel.: +1-617-3244051. E-mail: athanasios.orphanides@mit.edu. 
Marvin Goodfriend's (2014) insightful, informative and provocative work explains concisely and convincingly why the Fed needs rules and boundaries. Fundamentally, I agree with the concern Goodfriend identifies and the reasoning he provides. The concern is a serious one. As he points out in the introduction: "The lesson from the Fed's first century is that wide operational and financial independence given to monetary and credit policy subjects the Fed to incentives detrimental for macroeconomic and financial stability." (p.1-2.) Once this is acknowledged, it becomes clear why we should strive to improve the current framework. Rules and boundaries are needed to avoid conflicting and sometime impossible demands on the central bank that lead to bad economic outcomes.

Goodfriend's paper recounts examples that raise concern regarding both monetary policy and what is called credit policy, a term used to describe lending facilities such as the provision of emergency liquidity assistance (ELA).

On monetary policy, Goodfriend brings back the ghosts of the Great Inflation era. In the absence of clear rules, and with a muddled objective that simultaneously instructs the Fed to achieve maximum employment and price stability, the Federal Reserve faces the risk of excessive influence by the shifting balance of public concerns for inflation and unemployment. The risk is that monetary policy becomes dominated by short-term considerations, which makes monetary policy a source of instability, worsening both unemployment and inflation outcomes.

This is very much a current concern. Following a painful recession in the aftermath of the recent crisis, short-term dissatisfaction with elevated unemployment has created incentives for the Fed to overemphasize maximum employment as a policy objective. The Federal Reserve's decision two years ago to adopt a framework where monetary policy was explicitly guided with reference to a numerical threshold for the unemployment rate was quite troubling for anyone familiar with these risks and the troubled history of the Federal Reserve. I consider it a positive development that the Federal Reserve has reversed its earlier decision and has dropped this explicit guidance.

On credit policy, the key issue is that some of the actions in which the Federal Reserve gets involved, including during the recent crisis, are effectively equivalent to fiscal operations. In a democracy, however, fiscal operations should not be within the purview of the central bank. In a democracy, elected government is assigned the responsibility to spend public resources and faces the accountability for fiscal policy. The risk, in the case of credit policy, is that the central bank's independence can be abused to take actions and make decisions outside its scope of competence and accountability. Goodfriend reaches the controversial conclusion that: "The Fed's very independence, the ambiguous boundary of expansive Fed credit policy itself, would exacerbate the financial panic in September 2008 that would produce the Great Recession." 
(p.11.) Whether the ambiguity of the Fed's credit policies and the actions taken in 2008 exacerbated the Great Recession is something I believe will be under discussion for generations, similar to the study of what happened in the $1930 \mathrm{~s}$. I'm not ready to draw a definite conclusion on this point but I find the issue of great concern and, as will become clear later, a concern that applies to other central banks as well. Similar to the case of monetary policy, the issue is that even a central bank that may generally behave in a systematic fashion has tremendous discretion on numerous actions. This discretion entails costs. If it is feasible to redesign the system to ensure that discretion is limited by better rules and stricter boundaries so that central bank policy cannot add instability to the economy, this should be pursued.

Marvin Goodfriend goes on to identify the governance problem associated with an independent central bank and describes principles meant to solve the problem. "Congress bestows Fed independence only because it is necessary for the Fed to do its job effectively. Hence, the Fed should perform only those functions that must be carried out by an independent central bank. The problem is to identify the limits of independence on credit policy to preserve a workable, sustainable division of responsibilities between the central bank and the fiscal authorities---the legislature and the Treasury." (p. 20.)

The broader institutional design problem is about what a central bank should be doing and how its effectiveness can be safeguarded. The issue can be framed with questions: How can a central bank best contribute to society? What should the central bank's objectives be? How much discretion should be encouraged or tolerated? Is it sufficient to delegate the task to "independent" authorities? How can an independent central bank be held accountable?

The ideal institutional design of the central bank is a long standing problem. Broad agreement has been reached on the desirability of delegating central bank tasks to independent authorities. But this may not be enough. Goodfriend argues for the need to impose additional boundaries and constraints. Even then, one may question if this is sufficient to solve the problem.

The question goes back at least to the 1936 discussion on "Rules versus Authorities" by Henry Simons: "Our problem is that of defining an adequate monetary system based on simple rules and of finding the way toward such a system." (Simons, 1936, p. 4.) The risks emanating from discretionary power left to governments was identified already a century earlier by David Ricardo. In his 1824 Plan for the establishment of a National Bank, Ricardo identified the problem of letting governments control paper money: "It is said that Government could not be safely entrusted with the power of issuing paper money; that it would most certainly abuse it; and that, on any occasion when it was pressed for money to carry on a war, it would cease to pay coin, on demand, for its notes; and from that moment the currency would become a forced 
Government paper. There would, I confess, be great dangers of this, if Government---that is to say, the Ministers---were themselves to be entrusted with the power of issuing paper money."

Ricardo proposed independence as the solution: The central bank should be governed by individuals "entirely independent" of the government's Ministers who "should never, on any pretence, lend money to Government, nor be in the slightest degree under its control or influence." However one reads Ricardo's proposed solution, it is easy to identity why Goodfriend's examples of fiscal operations undertaken by the independent Federal Reserve during the crisis are a cause of concern.

What should the scope of central bank objectives be? There is wide agreement on some tasks: price stability, economic stability, financial stability. These are legitimate objectives reflecting what any stability-oriented central bank should be concerned with. But there is disagreement about additional objectives, and this is why some central banks end up with muddled mandates and ambiguous responsibilities. Should "maximum employment" be a central bank task? How about "widely diffused well-being"? Or "fiscal transfers to failed institutions"?

These are additional objectives that quite often government and the public expect central banks to be involved in. These additional objectives are responsible for the conflicts Goodfriend identifies as counterproductive. Consider the notion of "widely diffused wellbeing." Shouldn't this be an objective we should want all authorities to aim at? Isn't this what we would like to achieve in a democratic society? Certainly, widely diffused well-being is a desirable social objective, much like maximum employment. The question is whether it is a legitimate central bank objective. Going back to 1939, in the first edition of the Federal Reserve's Purposes and Functions, we find the following characterization of the central bank's objectives: "The purpose of Federal Reserve functions, like that of Governmental functions in general, is the public good. Federal Reserve policy can not be adequately understood, therefore, merely in terms of how much the Federal Reserve authorities have the power to do and how much they have not the power to do. It must be understood in the light of its objective---which is to maintain monetary conditions favorable for an active and sound use of the country's productive facilities, full employment, and a rate of consumption reflecting widely diffused well-being."

Central bank objectives and their interpretation may reflect good intentions but this is not sufficient to deliver good results. Expansive objectives and interpretations become counterproductive. The Fed's interpretation of its objectives in 1939 serves as an example. I don't think anybody would identify the 1930 s as a brilliant period of Federal Reserve policy.

Problems arise when the central bank is overburdened. Political dynamics quite often lead to this outcome. As a powerful and independent agency, the central bank is often seen as 
providing the easy way out of politically costly problems. But there are inter-temporal costs and benefits associated with central bank decisions. The problem with discretion is the incentive it provides to shift costs to the future in exchange for a perceived small short-term gain. High expectations can lead to the situation where a central bank with a mandate that lacks clarity may be cornered by the political establishment and public pressure, with no good choices left.

At the margin, easy money can create "more jobs" today. Who doesn't want more jobs today? Other things equal, everybody wants more jobs today. The problem is to recognize that overheating the economy to deliver more jobs today simply shifts costs down the road in the form of high inflation, and eventually stagnation. We need independent, rules-driven monetary policy to avert shifting these costs to the future.

Similarly, at the margin, extending credit to a failed institution today can prolong a "feel good" environment and postpone tough decisions. Most of the time, such delays increase the cost of a crisis and shifts it further to the future.

In assigning tasks to an independent agency, society tries to solve problems of human nature and human interactions, problems such as dynamic inconsistency and moral hazard. As long as discretion is permitted and objectives are unclear, these problems remain. The independence of the central bank is not enough. Rules and boundaries are absolutely essential.

How can the Federal Reserve's current flaws be corrected? On monetary policy it's relatively simple. At the moment, the Federal Reserve is hampered by lack of clarity in its mandate. Multiple incompatible objectives are stated jointly in the legislation. What is required is a simplification that clarifies the primacy of price stability as a monetary policy objective for the Federal Reserve. ${ }^{1}$ All other socially desirable objectives, including maximum employment should be recognized as secondary to price stability. This is the best way monetary policy can contribute to society.

Frankly, I think this is the easy part. The tougher part is what to do about credit policy. At present, the Federal Reserve is hampered by the expectation that it will bail out failed institutions, as long as it is believed that their demise might be harmful to the economy.

The Federal Reserve's discretionary power to engage in fiscal operations generates moral hazard and dynamic inconsistency. A way forward could be to demand that two conditions be met to rule out fiscal operations under the guise of credit policy. Extending credit to any institution could be prohibited unless the institution is solvent and adequate collateral is posted.

\footnotetext{
${ }^{1}$ See Orphanides (2014a) for a more detailed exposition of the argument.
} 
Adopting these rules would be a step in the right direction. But is it enough? When I reached this point in the analysis I realized that the proposed framework for improving the Federal Reserve is a familiar one. Having spent five years during the crisis in Europe, I could identify the framework just outlined as consistent with what is already in place in Europe. Regarding monetary policy, the European Union Treaty protects the independence of the European Central Bank (ECB) and the national central banks (NCBs) of all member states and assigns to central banks the primary mandate of price stability. Regarding credit policy, monetary financing is strictly prohibited and emergency liquidity assistance is supposed to be provided only when the two conditions identified above are met: To receive ELA an institution must be solvent and post adequate collateral.

I read the main conclusion of Goodfriend's paper as the need for rules and boundaries. I agree. But how can we ensure that these rules and boundaries are respected as intended when they are formulated? How do we deal with the residual discretion that may remain in the interpretation of the rules? Since the European Union already has in place the framework that is suggested to improve the Federal Reserve, it presents a laboratory to examine if what is suggested is sufficient to solve the underlying problem.

Residual discretion may be particularly problematic during a crisis. An example of the difficulty is reflected in Paul Volcker's April 2008 reaction to Fed credit policy decisions, when he stated that the Fed was operating "at the very edge of its lawful and implied powers." (Goodfriend, 2014, p. 11.)

During a crisis, interpreting the legal boundaries of action often rests on figuring out how to parse a grey figure into black and white. Policymakers may face a picture of grey regarding possible actions and need to figure out what is the white area that falls within the boundaries and what is the black area that falls outside the boundaries. Sometimes policymakers may run into difficulties in doing this. Who is responsible for damages if the central bank is not operating in the white part of the grey area?

Even worse, there is a risk of deliberate abuse of the central bank's discretionary powers. During a crisis, a picture that might have appeared black and white to an outside observer can be muddled by the central bank. Novel interpretations of the legal authority of the central bank may be introduced to create a grey area that might be exploited to justify decisions that would appear to be clearly outside the boundaries to an outside observer.

As an example for reflection, let me draw on a case from Europe. Consider what happened in Cyprus in March 2013. Watching events unfold from the United States offered a clear example of what can go wrong with credit policy decisions even with rules and boundaries in place. 
You may recall that in March 2013, immediately following Presidential elections and the formation of a new government in Cyprus, European governments decided to impose a haircut on deposits in Cypriot banks. The subsequent collapse destroyed the Cypriot banking system and imposed horrendous economic losses on the island. ${ }^{2}$

An independent investigation that was conducted a few months after the collapse documented an important role of central bank credit policy (ELA) for the outcome (Zenios, 2013). ${ }^{3}$ According to the findings, between May 2012 and March 2013, central bank credit policy extended about 6 billion euro of additional liquidity to Marfin-Laiki Bank. The bank was subsequently let to fail and the delay in resolving the situation led to a haircut of deposits of about 6 billion euro in March 2013. According to the investigation, the provision of ELA during this period appears to have violated both principles that were supposed to be met under the law governing central banks in Europe. Specifically, Marfin-Laiki apparently was insolvent before March 2013 and the collateral posted by the bank proved not to have been adequate for the ELA granted to it. ${ }^{4}$

An inescapable conclusion stemming from the Zenios (2013) analysis is that had the ECB/CBC respected the rules regarding the provision of ELA for Marfin-Laiki Bank, the ELA to that bank would have stopped many months earlier, when costs of resolving the situation would have been far smaller. By using their discretionary powers to extend ELA to Marfin-Laiki Bank long after it should have stopped, the ECB/CBC effectively transformed a manageable problem in one institution into an unmanageable catastrophe for the economy of the country.

Statements by central bankers involved in granting the ELA before the collapse are informative about what may have gone awry. ${ }^{5}$ One may wonder why Marfin-Laiki Bank was kept alive until March 2013. As CBC Governor Panicos Demetriades explained in an interview a few days after the collapse: "This was not something pleasant, but we had to sustain the bank. It was required to sustain the bank in order for the elections to take place, ..." (Palala, 2013, author translation). One may wonder why ELA was provided if the bank was insolvent. The ECB Executive Board Member involved explained this apparent paradox while responding to a question at a hearing of the European Parliament in May 2013. Specifically, Joerg Asmussen said: "You can receive ELA by your National Central Bank only when you are solvent or when

\footnotetext{
${ }^{2}$ See Orphanides (2014b) and references therein for additional background and details regarding these events.

${ }^{3}$ In the eurosystem, ELA is provided by an NCB with approval of the ECB Governing Council so both the ECB and the Central Bank of Cyprus (CBC) had a role in the implementation of the policy. It is beyond the scope of this example to elaborate on the sticky legal issues involved in parsing responsibility among the two.

${ }^{4}$ To protect against losses for the ELA provided with inadequate collateral, the central bankers involved engineered a forced merger of the failed bank with a healthier bank and used deposits from the healthier bank to cover the loss. (Xiouros, 2013.) As would be expected, numerous legal challenges are currently in process.

${ }^{5}$ The unprecedented publication on March 21, 2013 of a press release by the ECB Governing Council regarding the continuation of provision of ELA is also informative (European Central Bank, 2013). Among others, the statement effectively affirmed that the ECB Governing Council had the authority to discontinue the provision of ELA.
} 
there is a clear perspective that the bank can become solvent again while it is recapitalized as part of an adjustment program." (European Parliament, 2013.) Drawing on these statements, one might reach the conclusion that despite central bank independence and the clear rules and boundaries regarding $E C B / C B C$ provision of ELA, what should have been black and white may have turned into grey in the eyes of the policymakers involved before March 2013. Political considerations associated with the February 2013 elections in Cyprus appear to have determined the continuation of ELA provision. The requirement that a bank should be solvent to qualify for the provision of ELA appears to have been relaxed so that ELA could be provided to an insolvent bank.

The case of ELA provision in Cyprus before the collapse of March 2013 offers a clear illustration of the difficulty of limiting harmful discretion with rules and boundaries. The central bank may be able to create the grey area it needs to circumvent rules and boundaries and create additional room to exercise the very discretionary powers that the rules and boundaries are meant to stop.

Regardless of whether the provision of ELA to Marfin-Laiki Bank in the months leading to March 2013 fell onto the white or the black area of the grey figure, the $E C B / C B C$ decisions vastly increased the cost subsequently imposed on the people of Cyprus. Who is responsible for damages if the $E C B / C B C$ was not operating in the white area?

This example leaves us with a challenge. I believe we can agree that we need to ensure central bank independence. I believe we should agree that we need to clarify the mandate of central banks to focus on the narrow, well-defined objectives that central banks can achieve. I agree with Goodfriend's thesis, that this is not enough and that we need to define rules and boundaries to limit the discretionary power of central bankers that can cause so much havoc in our societies. But I am left wondering how to ensure that the rules and boundaries are respected. At the end of the day, it's people who take the decisions and there are limits to human nature. Are rules and boundaries sufficient to guard us against human failings? 


\section{References}

European Central Bank (2013). Governing Council decision on Emergency Liquidity Assistance requested by the Central Bank of Cyprus. Press release, March 21.

https://www.ecb.europa.eu/press/pr/date/2013/html/pr130321.en.html

European Parliament (2013). Hearing on financial assistance to Cyprus. Economic and Monetary Affairs Committee of the European Parliament. Video, May 8.

http://www.europarl.europa.eu/ep-live/en/committees/video?event=20130508-0930COMMITTEE-ECON

Federal Reserve Board (1939). The Federal Reserve System: Its Purposes and Functions. Washington, DC: Federal Reserve.

Goodfriend, Marvin (2014). Lessons from a Century of Fed Policy: Why Monetary and Credit Policies Need Rules and Boundaries. Paper presented at the Hoover Institution conference Frameworks for Central Banking in the Next Century, May 29-30, 2014.

Orphanides, Athanasios (2014a). The need for a price stability mandate. CATO Journal, 34(2) Spring/Summer. http://object.cato.org/sites/cato.org/files/serials/files/catojournal/2014/5/cato-journal-v34n2-4.pdf

Orphanides, Athanasios (2014b). The euro area crisis: Politics over economics. Atlantic Economic Journal 42(3), September. http://dx.doi.org/10.1007/s11293-014-9419-1

Palala, Nansia (2013). Towards removing the governor. Simerini, 27 March. (In Greek.)

Ricardo, David (1824). Plan for the establishment of a National Bank. London: John Murray. http://oll.libertyfund.org/title/1395/83017

Simons, Henry (1936). Rules versus authorities in monetary policy. Journal of Political Economy, 44(1), February.

Xiouros, Costas (2013). Handling of the emergency liquidity assistance of Laiki bank in the bailout package of Cyprus. Working paper, University of Cyprus, April. http://papers.ssrn.com/sol3/papers.cfm?abstract id=2254499

Zenios, Stavros (2013). The collapse of the Cyprus economy: From misjudgment to mismanagement. Report to the Special Investigation Committee for the Cyprus economy. Nicosia, September. (In Greek.) 


\section{IMFS WORKING PAPER SERIES}

\section{Recent Issues}

83 / 2014 Tobias H. Tröger

$82 / 2014$

$81 / 2014$

$80 / 2014$

$79 / 2014$

$78 / 2014$

77 / 2014

$76 / 2013$

$75 / 2013$

74 / 2013

$73 / 2013$

72 / 2013

$71 / 2013$

$70 / 2013$

Markus Behn
Y. Emily Yoo

Rainer Haselmann

Vikrant Vig

Volker Wieland

Maik Wolters

Hermann Remsperger

Athanasios Orphanides

Michael Binder

Marcel Bluhm

Helmut Siekmann

Athanasios Orphanides

Tilman Bletzinger

Volker Wieland

Tobias H. Tröger

Matthias Burgert

Sebastian Schmidt

Helmut Siekmann

Volker Wieland

Elena Afanasyeva
How Special Are They? - Targeting Systemic Risk by Regulating Shadow Banking

The Limits of Model-Based Regulation

Is there a threat of self-reinforcing deflation in the Euro area? A view through the lens of the Phillips curve

Der makroprudenzielle Komplex: der Prozess, das Schloss, das Urteil

What Happened in Cyprus? The Economic Consequences of the Last Communist Government in Europe

On the Conditional Effects of IMF Loan Program Participation on Output Growth

Zur Offenlegung der Bezüge von Sparkassenführungskräften im Internet

Financial Regulation and Supervision Across Business Lines in the United States - Financial Holding Companies post Gramm-Leach-Bliley Act

Is Monetary Policy Overburdened?

Estimating the European Central Bank's "Extended Period of Time"

The Single Supervisory Mechanism Panacea or Quack Banking Regulation?

Dealing with a Liquidity Trap when Government Debt Matters:

Optimal Time-Consistent Monetary and Fiscal Policy

The European Central Bank's Outright Monetary Transactions and the Federal Constitutional Court of Germany (publ. partially as "The question before the court", in: Economist, June 18, 2013)

Atypical Behavior of Credit: Evidence from a Monetary VAR 
69 / 2013 Tobias H. Tröger

Konzernverantwortung in der aufsichtsunterworfenen Finanzbranche (publ. in: ZHR 2013, S. 475-517)

68 / $2013 \quad$ John F. Cogan John B. Taylor Volker Wieland Maik Wolters

Fiscal Consolidation Strategy: An Update for the Budget Reform Proposal of March 2013

67 I $2012 \quad \begin{array}{ll}\text { Otmar Issing } \\ \text { Volker Wieland }\end{array}$

Monetary Theory and Monetary Policy: Reflections on the Development over the last 150 Years

66 / $2012 \quad$ John B. Taylor Volker Wieland

Surprising Comparative Properties of Monetary Models: Results from a new Model Database

$65 / 2012$

Helmut Siekmann

Missachtung rechtlicher Vorgaben des AEUV durch die Mitgliedstaaten und die EZB in der Schuldenkrise (publ. in: Thomas M.J. Möller und FranzChristoph Zeitler (ed.), Europa als Rechtsgemeinschaft - Währungsunion und Schuldenkrise, Tübingen, 2013, pp.97154)

64 / 2012 Helmut Siekmann

Die Legende von der verfassungsrechtlichen Sonderstellung des „anonymen“ Kapitaleigentums (publ. in: Der grundrechtsgeprägte Verfassungsstaat, Festschrift für Klaus Stern zum 80. Geburtstag, herausgegeben von Michael Sachs und Helmut Siekmann, Berlin, 2012, pp. 1527-1541)

$63 / 2012$

Guenter W. Beck

On the Importance of Sectoral and Kirstin Hubrich

Massimiliano Marcellino

Regional Shocks for Price Setting

$62 \mid 2012$

Volker Wieland

Maik H. Wolters

Forecasting and Policy Making

$61 / 2012$

John F. Cogan John B. Taylor

Volker Wieland

Maik H. Wolters

Fiscal Consolidation Strategy (publ. in: Journal of Economic Dynamics and Control, Vol. 37 Issue 2 (February), pp. 404-21)

$60 / 2012$

Peter Tillmann Maik H. Wolters

The Changing Dynamics of US Inflation Persistence: A Quantile Regression Approach

59 / $2012 \quad$ Maik H. Wolters

Evaluating Point and Density Forecasts of DSGE Models 